\title{
Research of dynamic properties of alloys of AMg6BM and AMg6M in shock-wave experiment on a gas gun
}

\author{
S.S. Mokrushin, E.I. Karnaukhov, S.N. Malugina, D.N. Kazakov, O.E. Kozelkov, and A.V. Pavlenko ${ }^{a}$
}

FSUE Zababakhin RFNC-VNIITF, 456770, Snezhinsk

\begin{abstract}
Spall strength and elastoplastic parameters of aluminum alloys AMg6BM and AMg6M were studied in shock wave experiments with light gas guns LGG-1200 and LGG-2500 and results of these experiments are provided. Strength wave profiles were registered simultaneously by VISAR and interferometer PDV. Consideration was given to dependences of spall strength and strength parameters of aluminum alloys $\mathrm{AMg} 6 \mathrm{BM}$ and $\mathrm{AMg} 6 \mathrm{M}$ on the amplitude of the shock-wave loading in the range of 1.1 to $14.2 \mathrm{GPa}$ and on deformation rate in the range of 0.2 to $3.6 \cdot 10^{5} \mathrm{~s}^{-1}$. Threshold damage levels for alloys $\mathrm{AMg} 6 \mathrm{M}$ and $\mathrm{AMg} 6 \mathrm{BM}$ are determined. It was shown that alloy AMg6BM softens under the pressure more than $5 \mathrm{GPa}$.
\end{abstract}

\section{Introduction}

Aluminum alloys of the system Al-Mg (magnalia) combine good strength and high plasticity, have high processibility, are well distorted, have satisfactory corrosion resistance and good fusability. This determines wide application of these alloys in atomic industry, building industry, aviation, rocket building, in constructions subjected to high thermal and force loadings [1,2]. Russian industry proves semifinished alloy $\mathrm{AMg} 6$ in the form of sheets, rods, foils, profiles in thermally unprocessed (AMg6), annealed (AMg6M), with technological cladding of sheets (AMg6BM) or without cladding (AMg6M), in cold-worked $(\mathrm{AMg} 6 \mathrm{~N})$ and other states of products. Prediction of the results of pulse impact on such structures is an important practical task. In order to solve this task, it is necessary to know dynamic, kinematic and thermophysical properties of such structures $[3,4]$.

Authors of [5-8] got the first experimental data on strength characteristics of alloys AMg6 and AMg6M in the conditions of explosive impact with microsecond duration of loading pulse at deformation rate in the range of $10^{3}$ to $10^{6} \mathrm{~s}^{-1}$ and the temperature in the range of $\left(-13{ }^{\circ} \mathrm{C}\right)$ to $+550^{\circ} \mathrm{C}$. However, specialists performing experiments described in [5-8] used various approaches in measuring techniques. In activities [5-7], the fact of presence or absence of a spall was determined by visual examination or metallographic study of the samples that were recovered after experiments, and determination of the values of destructing stresses was made by assessment methods (using acoustic spall theory or EOS of the sample material and impactor). In [8], for determination of values of destructing stresses, the authors used profiles of rate $W(t)$ that were obtained with the help of capacitive pickup of pressure. The use of various measuring methods led to sufficient disagreement of experimental results [5-8],

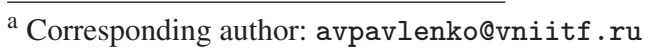

especially while determining threshold levels of samples destruction $(\sim$ by a factor of 2$)$.

While experimental equipment was developed in [9, 10], the study of dynamic properties of $\mathrm{AMg} 6 \mathrm{M}$ was continued. Registration of profiles of free surface of samples was made with the help of laser-interferometric measuring methods. As the result, new experimental data on dynamic properties of $\mathrm{AMg} 6 \mathrm{M}$ at deformation rate in the range of $10^{3}$ to $10^{6} \mathrm{~s}^{-1}$, pressure from 2 to $56 \mathrm{GPa}$, temperature from +20 to $+600{ }^{\circ} \mathrm{C}$ were obtained at qualitatively new level. Dynamic properties of AMg6 at deformation rate $190-1450 \mathrm{~s}^{-1}$ using split Hopkinson bar were studied by the authors of [11].

However, high deformation rates and loading levels realized under using explosive devices did not permit to study in details the regions with transition from elastic to plastic deformation. That is why it is more expedient to use such experimental data for building wide-range mathematical models $[3,4]$. The development of up-to-date models of elasto-visco-plastic deformation of structural materials $[12,13]$ that are used at our Institute is performed by comparison of experimental profiles of free surface velocity for materials under study and calculation data. In order to accurately determine numerical codes [12], select parameters of material model [13], one needs detailed investigation into dynamic properties of materials with smooth change of deformation rate and amplitude of shock-wave impact. It is necessary to note that comparison of strength properties of AMg6 samples fabricated out of rod and sheet material was performed only in $[5,7]$ in the field of pressures up to $3 \mathrm{GPa}$ while investigating threshold levels of the sample destruction. That is why the question about the influence of technological processing of materials on dynamic properties of $\mathrm{AMg} 6 \mathrm{M}$ and AMg6BM samples remains unclear. Authors of $[14,15]$ paid much attention to this topic.

This presentation gives the results of investigation into dynamic properties of aluminum alloy $\mathrm{AMg} 6 \mathrm{M}$ and alloy $\mathrm{AMg} 6 \mathrm{BM}$. Contrary to $[6,8-10]$, in order to clarify the 


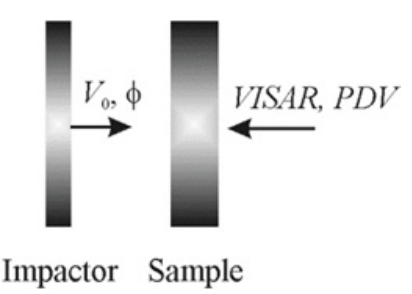

Figure 1. Scheme of loading and measuring methods.

influence of technological processing on the properties of materials under study, the samples were fabricated out of AMg6M KR40 rod (GOST 21488-97) and AMg6BM 5 sheet (GOST 21631-76).

Investigation was performed on two one-stage light gas guns [16] according to method of impact with simultaneous use of two-channel interferometer VISAR [17] and interferometer PDV [18]. The pressure in the samples was varied in the range from 1.1 to $14.2 \mathrm{GPa}$, deformation rate - in the range from 0.2 to $3.6 \cdot 10^{5} \mathrm{~s}^{-1}$.

Experimental data were obtained in the form of profiles of free surface velocity $W(t)$ for each type of samples of AMg6M and AMg6BM. Experimental data were processed and analyzed, the values of spall strength, dynamic yield limit, elastic limit and shear stress were determined. Threshold values of pressure were also determined, under which, spall destruction begins. For each material, dependences of spall strength on amplitude of loading pulse and deformation rate were built. Experimental profiles were used for determination of parameters of Johnson-Cook material model with MieGruneisen.

\section{Experimental equipment}

Experimental studies of dynamic properties of aluminum alloy samplesAMg6M and $\mathrm{AMg} 6 \mathrm{BM}$ were performed on light gas guns (LGG) with caliber $44 \mathrm{~mm}$. Collision velocity was varied in the range of 0.2 to $2 \mathrm{~km} / \mathrm{s}$. Figure 1 shows the scheme of alloys samples loading and applied measuring methods.

In all experiments, evolution of shock waves in the samples of $\mathrm{AMg} 6 \mathrm{M}$ and $\mathrm{AMg} 6 \mathrm{BM}$ was studied. In experiments with aluminum alloy $\mathrm{AMg} 6 \mathrm{M}$, the technology of forming high deformation rates was probed at the cost of using impactors out of tantalic foils. Data on experiment set-up are given in Tables 1 and 2.

The velocity of impactor collision with the sample $V_{0}$ was determined with the help of electro-contact gauges. In addition, they determined the value of a slope, which characterized disalignment (distortion $\varphi$ ) of collided surfaces of impactor with the sample. Registration of profiles of stress waves was made simultaneously with the help of two-channel laser-interferometric complex VISAR and interferometer PDV. That permitted to make registration of velocity profiles $W(t)$ with an error less than $9 \mathrm{~m} / \mathrm{s}$ and time resolution at least $2,2 \mathrm{~ns}$.

We are investigated aluminum alloy made out of a sheet AMg6BM 5 (GOST 21631-76) and rod AMg6M KR40 (GOST 21488-97). Metallographic analysis of the check test piece for alloy $\mathrm{AMg} 6 \mathrm{M}$ confirmed the presence
Table 1. Data on experiment set-up with the samples out of aluminum alloy AMg6BM.

\begin{tabular}{|c|c|c|c|c|}
\hline No & $\begin{array}{c}\text { Impactor } \\
\text { AMg6M, } \\
\mathrm{mm}\end{array}$ & $\begin{array}{c}\mathrm{V}_{0}, \\
\mathrm{~m} / \mathrm{s}\end{array}$ & $\begin{array}{c}\varphi, \\
\mathrm{mrad}\end{array}$ & $\begin{array}{c}\text { Sample } \\
\text { AMg6BM, } \\
\mathrm{mm}\end{array}$ \\
\hline 025 & 2.02 & 599 & 3.00 & 3.80 \\
\hline 026 & 1.99 & 869 & 2.34 & 3.80 \\
\hline 027 & 2.01 & 383 & 1.42 & 3.80 \\
\hline 028 & 2.01 & 227 & 1.54 & 3.80 \\
\hline 029 & 2.02 & 164 & 0.92 & 3.81 \\
\hline 031 & 2.00 & 231 & 0.78 & 3.80 \\
\hline 032 & 2.01 & 223 & 0.25 & 3.80 \\
\hline 036 & 2.01 & 158 & 0.93 & 3.80 \\
\hline 040 & 2.04 & 196 & 0.30 & 3.81 \\
\hline 220 & 2.06 & 1688 & 10.37 & 3.81 \\
\hline 221 & 2.02 & 1449 & 3.69 & 3.80 \\
\hline
\end{tabular}

Table 2. Data on experiment set-up with the samples out of aluminum alloy AMg6M.

\begin{tabular}{|c|c|c|c|c|c|}
\hline No & $\begin{array}{c}\text { Impactor } \\
\text { material }\end{array}$ & $\begin{array}{c}\text { Thickness, } \\
\mathrm{mm}\end{array}$ & $\begin{array}{c}\mathrm{V}_{0}, \\
\mathrm{~m} / \mathrm{s}\end{array}$ & $\begin{array}{c}\varphi, \\
\mathrm{mrad}\end{array}$ & $\begin{array}{c}\text { Sample } \\
\text { AMg6M, mm }\end{array}$ \\
\hline 044 & AMg6M & 2.05 & 855 & 1.10 & 3.99 \\
\hline 047 & AMg6M & 2.00 & 570 & 0.75 & 3.99 \\
\hline 048 & AMg6M & 2.04 & 369 & 0.25 & 4.00 \\
\hline 050 & AMg6M & 2.04 & 232 & 0.9 & 3.99 \\
\hline 051 & AMg6M & 1.98 & 184 & 1.32 & 4.00 \\
\hline 053 & AMg6M & 2.01 & 212 & 0.94 & 4.00 \\
\hline 054 & Tantalum & 0.05 & 568 & 1.02 & 4.00 \\
\hline 058 & Tantalum & 0.05 & 569 & 1.92 & 2.03 \\
\hline 229 & AMg6M & 2.02 & 1252 & 1.74 & 4.02 \\
\hline 230 & AMg6M & 2.03 & 1844 & 21.4 & 4.01 \\
\hline 231 & Tantalum & 0.05 & 1285 & 11.0 & 3.99 \\
\hline 234 & AMg6M & 2.04 & 2000 & - & 4.00 \\
\hline
\end{tabular}

Table 3. Chemical composition (in \%) of alloy AMg6 (GOST 4784-97).

\begin{tabular}{|c|c|c|c|c|}
\hline $\mathrm{Al}$ & $\mathrm{Cu}$ & $\mathrm{Mg}$ & $\mathrm{Mn}$ & $\mathrm{Fe}$ \\
Base & $<0.1$ & $5.8-6.8$ & $0.5-0.8$ & $<0.4$ \\
\hline $\mathrm{Si}$ & $\mathrm{Zn}$ & $\mathrm{Ti}$ & $\mathrm{Be}$ & Sum of impurities \\
$<0.4$ & $<0.2$ & $<0.10$ & $<0.005$ & 0.1 \\
\hline
\end{tabular}

Table 4. Chemical composition (in \%) of cladding layer (GOST 21631-76).

\begin{tabular}{|c|c|c|c|c|c|}
\hline $\begin{array}{c}\text { Alloying } \\
\text { components }\end{array}$ & \multicolumn{5}{|c|}{ Impurities, not more than } \\
\hline $\mathrm{Al}$ & $\mathrm{Fe}$ & $\mathrm{Sr}$ & $\mathrm{Cu}$ & $\mathrm{Mn}$ & Sum of \\
Not less & 0.30 & 0.30 & 0.02 & 0.025 & permissible \\
impurities \\
\cline { 2 - 6 } than 99.30 & $\mathrm{Zn}$ & $\mathrm{Ti}$ & $\mathrm{Mg}$ & Other & 0.70 \\
& 0.1 & 0.15 & 0.05 & impurities 0.02 & 0.70 \\
\hline
\end{tabular}

of alternating big and small grains, and this fact speaks about thermal processing of material. The size of big grains was (76 \pm 23$) \mu \mathrm{m}$, the size of small ones was (15 \pm 4$) \mu \mathrm{m}$. Table 3 shows the chemical composition of alloy AMg6 (GOST 4784-97).

For cladding of sheets, aluminum with chemical composition shown in the Table 4 is used.

Before experiments, mass and geometrical sizes of each sample we are measured. According to them, the 
Table 5. Data on the sound velocity in the samples of alloysAMg6BM and $\mathrm{AMg} 6 \mathrm{M}$.

\begin{tabular}{|c|c|c|c|}
\hline Material & $\mathrm{C}_{\mathrm{l}}, \mathrm{m} / \mathrm{s}$ & $\mathrm{C}_{\mathrm{s}}, \mathrm{m} / \mathrm{s}$ & $\mathrm{C}_{0}, \mathrm{~m} / \mathrm{s}$ \\
\hline $\mathrm{AMg} 6 \mathrm{BM}$ & $6460 \pm 15$ & $3167 \pm 15$ & 5325 \\
\hline $\mathrm{AMg} 6 \mathrm{M}$ & $6487 \pm 15$ & $3197 \pm 15$ & 5334 \\
\hline
\end{tabular}

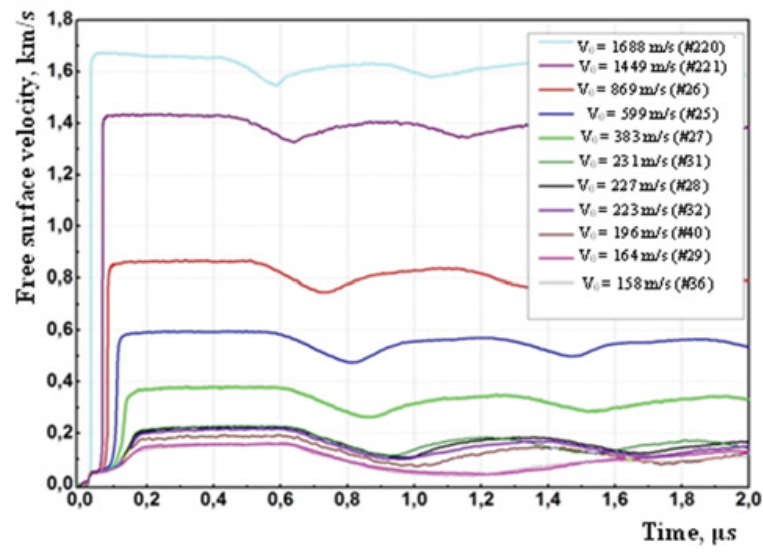

Figure 2. Profiles of free surface velocity in experiments with AMg6BM samples.

density of samples was calculated. The mass of samples was measured with the help of laboratory electronic scales of HR-I series. The diameter and thickness of all samples was measured by a linear displacement transducer with $10 \mu \mathrm{m}$ absolute accuracy. Measurement of each parameter of the sample was made 10 times. The error of measurements was calculated at reliability $P=0.95$ (Student's coefficient $t_{\alpha}=2.26$, at $n=10$ measurements of a parameter). Measured density of AMg6M samples was $\rho=2.62 \pm 0.02 \mathrm{~g} / \mathrm{cm}^{3}$, and density of AMg6BM samples was $\rho=2.62 \pm 0.01 \mathrm{~g} / \mathrm{cm}^{3}$.

Preliminary, the sound velocity was determined for the samples of AMg6M and AMg6BM. The velocity of longitudinal wave $C_{l}$ was determined using ultra sound thickness gauge T-MIKE E, and measurement of transverse wave velocity $C_{s}$ - using electromagnetic acoustic method of excitation and pick-up of ultra sound waves. Table 5 shows the data about sound velocity for mentioned samples.

\section{The results of studies}

The studies of dynamic properties of alloys $\mathrm{AMg} 6 \mathrm{~B}$ and $\mathrm{AMg} 6 \mathrm{M}$ we are made in two series of experiments (Tables 1 and 2). The presence of spall destruction was fixed according to appearance so called "spall" signals on amplitude-time dependences of free surface velocity $W(t)$ that speak about relaxation of stress waves under destruction in the samples [3]. The amplitude of shockwave impact was varied in the range of 1.1 to $14.2 \mathrm{GPa}$ (the range of collision velocity was from 0.15 to $2 \mathrm{~km} / \mathrm{s}$ ), deformation rate was from 0.2 to $3.6 \cdot 10^{5} \mathrm{~s}^{-1}$. Figures 2 and 3 show the profiles of free surface velocity $W(t)$ obtained in experiments with samples of AMg6BM and $\mathrm{AMg} 6 \mathrm{M}$, respectively.

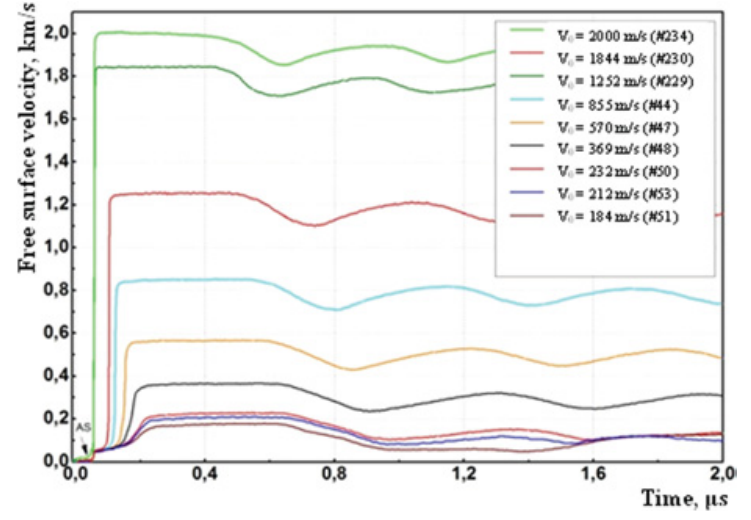

Figure 3. Free surface velocity profiles in the experiments with AMg6M alloy samples.

(a)

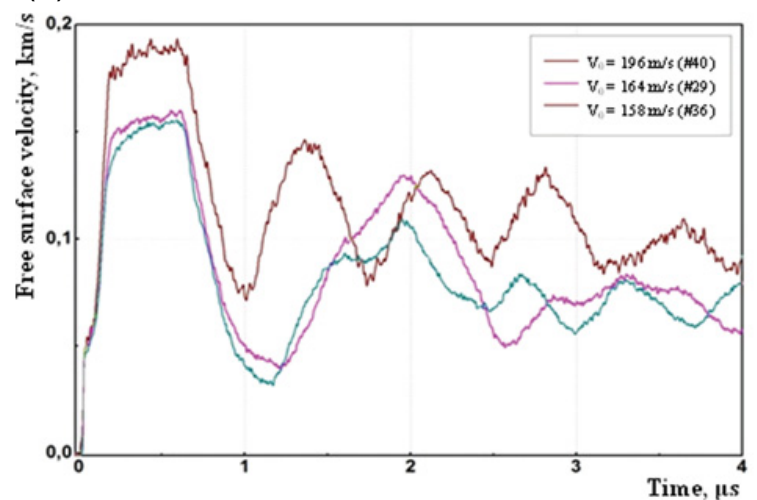

(b)

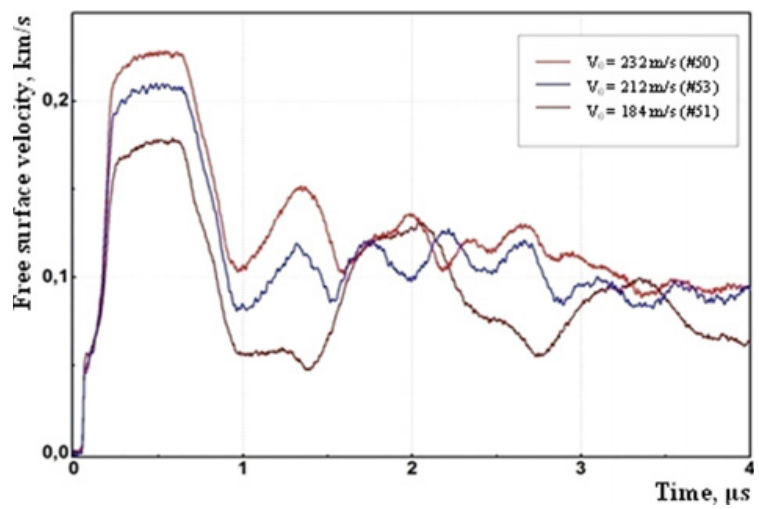

Figure 4. Velocity profiles $W(t)$ in the experiments with $\mathrm{AMg} 6 \mathrm{BM}$ (a) and $\mathrm{AMg} 6 \mathrm{M}$ (b) alloy samples.

Threshold damage levels for tested materials were determined during the work. Figure 4(a,b) contains velocity profiles $W(t)$ for $\mathrm{AMg} 6 \mathrm{BM}$ and $\mathrm{AMg} 6 \mathrm{M}$ alloys.

In Fig. 4(a,b) we can see, that spall pulse can be registered at a collision velocity higher than $196 \mathrm{~m} / \mathrm{s}$ (for $\mathrm{AMg} 6 \mathrm{BM}$ alloy) and $212 \mathrm{~m} / \mathrm{s}$ (AMg6M alloy). No damages, able to form spall signal, are caused at a collision velocity lower than $164 \mathrm{~m} / \mathrm{s}$ (for AMg6BM alloy) and $184 \mathrm{~m} / \mathrm{s}$ (for AMg6M alloy).

Deformation rate change in the relief part of the compression pulse was within the range from $0.2 \cdot 10^{5}$ to $1.6 \cdot 10^{5} \mathrm{~s}^{-1}$ at collision velocity range from 183 to $2000 \mathrm{~m} / \mathrm{s}$. In our work, we tried to extend the deformation 


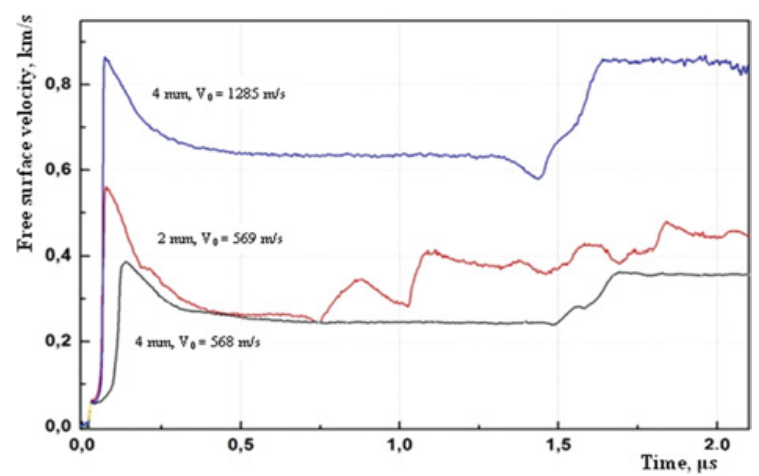

Figure 5. $W(t)$ velocity profiles in the experiments with $\mathrm{AMg} 6 \mathrm{M}$ alloy samples.

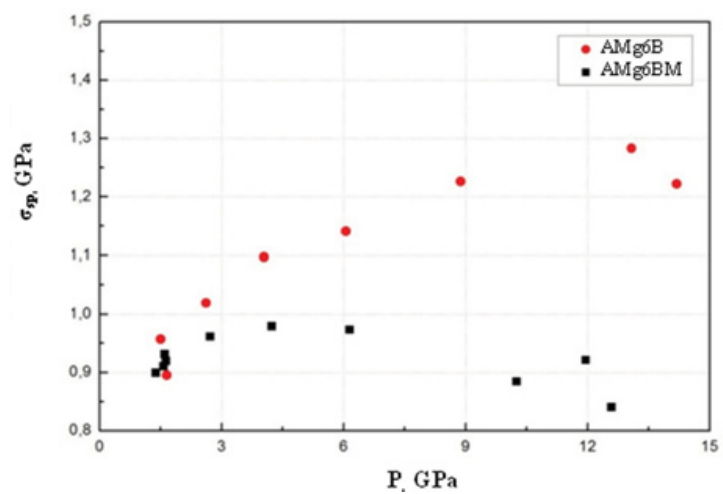

Figure 6. Spall strength of $\mathrm{AMg} 6 \mathrm{M}$ and $\mathrm{AMg} 6 \mathrm{BM}$ alloys samples depending on the amplitude of shock compression.

rate range using loading technology of $\mathrm{AMg} 6 \mathrm{M}$ alloy sample loading with tantalum foils $50 \mu \mathrm{m}$ thick. In Fig. 5, we can see free surface velocity profiles for AMg6M alloy; these profiles are formed in the samples with these strikers.

Technology used to form load pulses in the samples allowed to extend the deformation rate range to 3.6 . $10^{5} \mathrm{~s}^{-1}$. But spall signal under conditions shown in Table 2 was registered only in one experiment 48 . AMg6M alloy spall strength for this experiment was $\sigma_{\mathrm{sp}}=1.33 \mathrm{GPa}$.

Large number of experiments allowed to determine statistical straggling for the Hugoniot limit values $\left(\sigma_{\text {hel }}\right)$, shear stress values $\left(\tau_{\mathrm{T}}\right)$ and dynamic yield limit values $\left(\sigma_{\tau}\right)$. These parameters for $\mathrm{AMg} 6 \mathrm{M}$ alloy were the following: $\sigma_{\text {hel }}=0.42 \pm 0.03 \mathrm{GPa}, \tau_{\mathrm{T}}=0.10 \pm 0.01 \mathrm{GPa}, \sigma_{\tau}=$ $0.20 \pm 0.01 \mathrm{GPa}$. For AMg6BM alloy: $\sigma_{\text {hel }}=0.40 \pm$ $0.02 \mathrm{GPa}, \tau_{\mathrm{T}}=0.10 \pm 0.01 \mathrm{GPa}, \sigma_{\tau}=0.19 \pm 0.01 \mathrm{GPa}$.

In Figs. 6 and 7, we can see dependencies of spall strength for alloys $\mathrm{AMg} 6 \mathrm{M}$ and $\mathrm{AMg} 6 \mathrm{BM}$ on shock compression amplitude and on deformation rate, respectively.

In Figs. 6-7, we can see that spall strength of aluminum alloy $\mathrm{AMg} 6 \mathrm{M}$ monotonously increases with pressure increase in the sample in the range from 1.4 to $14.2 \mathrm{GPa}$. Nevertheless, changes in spall strength of $\mathrm{AMg} 6 \mathrm{BM}$ aluminum alloy bear clear-cut softening character at shock compression amplitudes higher than $5 \mathrm{GPa}$, and deformation rate higher than $0.5 \cdot 10^{5} \mathrm{~s}^{-1}$. It is hardly probable that cladding of AMg6BM sheets will change the material strength. The difference between

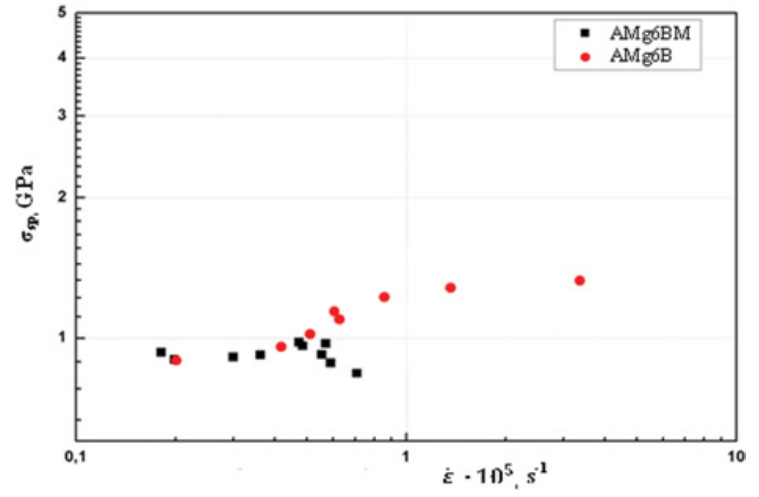

Figure 7. Spall strength of $\mathrm{AMg} 6 \mathrm{M}$ and $\mathrm{AMg} 6 \mathrm{BM}$ aluminum alloys samples depending on deformation rate.

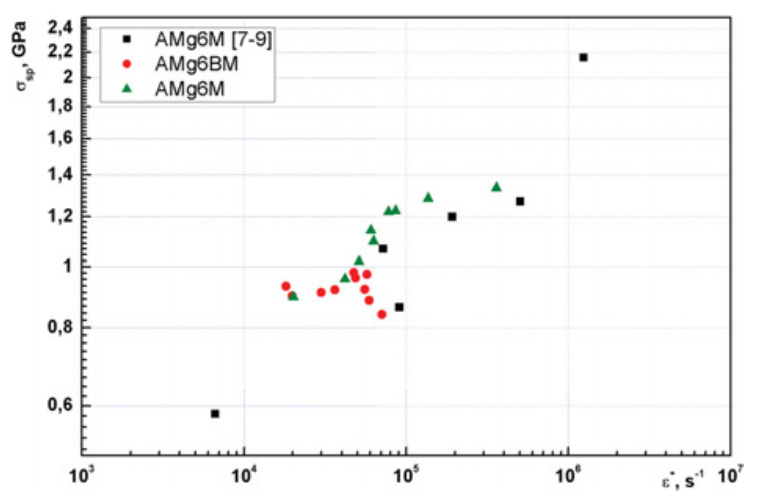

Figure 8. Spall strength of $\mathrm{AMg} 6 \mathrm{M}$ and $\mathrm{AMg} 6 \mathrm{BM}$ aluminum alloys samples depending on deformation rate.

$\mathrm{AMg} 6 \mathrm{M}$ and $\mathrm{AMg} 6 \mathrm{BM}$ lies only in the technologies of mechanical processing, which influences the material texture. All samples of AMg6BM alloy were manufactured out of the same sheet, thus intercrystalline corrosion of the material couldn't cause noticed alloy softening. It seems that material rolling changed its interior structure, which led to softening of the material AMg6BM.

Comparison of the experimental results, obtained using LGG, with the results, published in literature [8-10] (see Fig. 8), has shown that spall strength of bar material $\mathrm{AMg} 6 \mathrm{M}$ is significantly higher than the one of the sheet material AMg6M. The same destruction character was observed in earlier works [5,7] while studying threshold values for destruction of AMg6 alloy samples, made of bar and of sheet. But some new previously unnoticed peculiar features in material response to shock-wave loading were found in sheet material $\mathrm{AMg} 6 \mathrm{M}$ and $\mathrm{AMg} 6 \mathrm{BM}$. These features concerned deformation rate $10^{4}-10^{5} \mathrm{~s}^{-1}$.

\section{Conclusion}

This work covers the results of the study and comparison of the dynamic properties of the aluminum alloys AMg6M and $\mathrm{AMg} 6 \mathrm{BM}$. Aluminum alloys loading was performed by shock waves with submicrosecond length, amplitude from 1.1 to $14.2 \mathrm{GPa}$ and deformation rate from $0.2 \cdot 10^{5}$ to $3.6 \cdot 10^{5} \mathrm{~s}^{-1}$. As opposed to the works $[6,8-10]$, for this study, we used samples of alloys AMg6M and AMg6BM 
made of bars of AMg6M KR40 (GOST 21488-97) and sheet AMg6BM 5 (GOST 21631-76).

Experimental data is given in the form of sample free surface velocity profiles. Experimental results are analysed. Dependencies of spall strength on amplitude of shock-wave action $\sigma(P)$ and deformation rate $\sigma(\dot{\tau})$ are constructed.

The work results reveal that:

- the dependencies $\sigma(\mathrm{P})$ and $\sigma(\dot{\tau})$ for both sample materials monotonously increase up to the pressure of $5 \mathrm{GPa}$ and $\dot{\tau}=0.5 \cdot 10^{5} \mathrm{~s}^{-1}$;

- when pressure is higher than $5 \mathrm{GPa}$ and deformation rate is more than $0.5 \cdot 10^{5} \mathrm{~s}^{-1}$, softening of $\mathrm{AMg} 6 \mathrm{BM}$ alloy takes place;

- threshold values of spall strength were $\sigma=1.4 \mathrm{GPa}$ for $\mathrm{AMg} 6 \mathrm{BM}$ alloy, and $\sigma=1.5 \mathrm{GPa}$ for AMg6M alloy, respectively.

Experimental velocity $W(t)$ profiles obtained were used to determine the parameters of Jonson-Cook model of the material with Mie-Grüneisen equation of state. Experimental data satisfactorily agreed with numerical data.

\section{References}

[1] Physical material science, 6. Construction materials of nuclear power industry/Executive editor B. Kalin (2012)

[2] V. Belezkii, G. Krivov, Reference book: Aluminum alloys (composition, properties, technology, application) (2005)

[3] G. Kangel, V. Fortov, S. Razorenov, A. Utkin, Shockwave phenomena in condensed media (1996)
[4] E. Avrorin, B. Vodolaga, V. Simonenko, V. Fortov, Progress in Physical Science Magazine, 163, 5, 1-34 (1993)

[5] B. Tarasov, Strength problems, 3, 121-122 (1974)

[6] Yu. Batkov, S. Novikov, V. Sinitsin et al., PMTF, 3, 133-137 (1979)

[7] V. Golubev, S. Novikov, Yu. Sobolev, N. Yukina, Strength problems, 2, 53-59 (1983)

[8] G. Kanel, S. Razorenov, V. Fortov, PMTF, 5, 60-64 (1984)

[9] G. Kanel, S. Razorenov, V. Fortov, DAS USSR, 294, 2, 350-352 (1987)

[10] S. Razorenov, G. Kanel, V. Fortov, FMM, 95, 1, 9196 (2003)

[11] B. Glushak, O. Ignatova, V. Pushkov et al., PMTF, 41, 6, 139-142 (2000)

[12] A. Petrovtsev, G. Kovalenko, G. Zadorozhniy, Zababakhin Scientific Talks: Sourcebook of VII International conference - Snezhinsk; RFNC-VNIITV publishers (2003)

[13] Johnson G.R., Cook W.H., Proc. Of $7^{\text {th }}$ symposium of ballistics, Den Hague, Niderlands (1983)

[14] V. Chuveldeev, M. Gryaznov, V. Kopilov, A. Sisoev, Vestnik Nizhegorodskogo Universiteta, 4, 35-42 (2008)

[15] B. Kolachev, V. Elagin, V. Livanov. Physical metallurgy and thermal treatment of nonferrous metals and alloys (2005)

[16] A. Pavlenko, S. Balabin, O. Kozelkov, D. Kazakov, Instr. and Exp. Tech., 4, 122-124 (2013)

[17] A. Pavlenko, S. Malyugina, V. Pereshitov, I. Lisitsina, Instr. and Exp. Tech., 2, 127-129 (2013)

[18] S. Mokrushin, N. Anikin, S. Malyugina, A. Pavlenko, A. Tyaktev, Instr. and Exp. Tech., 4, 107-109 (2013) 